\title{
Risk factors for mortality and multiresistant bacteria in bloodstream infections acquired in a private hospital intensive care unit
}

\author{
JM Bonell Goytisolo ${ }^{1 *}$, I Jara Zozaya ${ }^{1}$, R Vento Rehues ${ }^{1}$, MT Millán Guilarte ${ }^{1}$, P Mas Morey ${ }^{2}$, FJ Montero Clavero ${ }^{1}$ \\ From ESICM LIVES 2015 \\ Berlin, Germany. 3-7 October 2015
}

\section{Introduction}

Nosocomial infections are a huge health problem worldwide, among them bacteremia are one of the most relevant in terms of morbidity and costs.

\section{Objective}

To study whether multiresistant bacterial (MRB) etiology and mortality of ICU-acquired bacteremia are associated with epidemiological and clinical factors of the episode and patient.

\section{Methods}

Retrospective, and cohort in the last 12 months, study of 70 consecutive episodes of bacteremia between 2011 and 2014 in a polyvalent 15 bed unit. Several items related to patient and episode are analyzed.

\section{Results}

Sixty-six different patients, median age 69 years (25-87). Most common origins were central catheter in 22 (31\%), lung in 15 (21\%) and abdomen in 10 (14\%). Gram-negative bacteria alone caused 32 cases $(46 \%$, Pseudomonas and Enterobacter were predominant, with 15 cases of MRB), Gram-positive 29 (41\%, coagulase-negative staphylococci was the most common), fungi in $9 \%$ and mixed origin in $4 \% .36$ patients $(55 \%)$ had been previously treated with broad spectrum antibiotics; 40 patients $(61 \%)$ were under mechanical ventilation, $52 \%$ were surgical, $23 \%$ with parenteral nutrition and $12 \%$ under renal replacement therapy. $36 \%$ of patients suffered from shock in the first $48 \mathrm{~h}$ of admission in ICU and 30\% had neoplasm or other inmunosupresive

${ }^{1}$ Hospital Quirón Palmaplanas, Intensive Care Unit, Palma de Mallorca, Spain Full list of author information is available at the end of the article situation at the admission. $14 \%$ of episodes had another previous infection caused by the same bacteria. In $26 \%$ of cases clinical manifestation of bacteremia was septic shock.

The presence of MRB had significant association with pulmonary origin (OR 4.8; CI 95\% $1.3-17$; $\mathrm{p}=0.02$ ), mechanical ventilation (OR 4.7; CI 95\% 1.2 - 18.5; $\mathrm{p}=$ 0.03 ) and a previous infection by the same germ (OR 11.7; CI 95\% 2.6 - 53; p < 0.01). Previous broad spectrum antibiotic therapy was related but was not significant.

Hospital mortality was $27 \%$, we found association with previous treatment with piperacilin-tazobactam (OR 3.7; CI 95\% 1.1 - 12.9; $\mathrm{p}=0.04$ ); other factors such as parenteral nutrition and septic shock complicated bacteremia did not reach statistical signification.

\section{Conclusions}

Acquired bacteremia in our unit is an heterogeneous complication attending to their origin and etiology. Risk factors for MRB were pulmonary source, mechanical ventilation and previous infection by the same bacteria. Mortality in our study was related to previous exposure to piperacilintazobactam, however we think that more cohort studies with large number of patients are required.

\section{Authors' details}

${ }^{1}$ Hospital Quirón Palmaplanas, Intensive Care Unit, Palma de Mallorca, Spain. ${ }^{2}$ Hospital Quirón Palmaplanas, Hospital Pharmacy, Palma de Mallorca, Spain.

\section{Published: 1 October 2015}

\section{References}

1. Vallés J, et al: Nosocomial bacteremia in critically ill patients: a multicenter study evaluating epidemiology and prognosis. Clin Infect Dis 1997, 24:387-395. 
2. Wisplinghoff $\mathrm{H}$, et al: Nosocomial bloodstream infections in US HJospitals: analysis of 24,179 cases from a prospective nationwide surveillance study. Clin Infect Dis 2004, 39(3):309.

3. Routsi $\mathrm{Ch}$, et al: Risk factors for carbapenem-resistant Gram-negative bacteremia in intensive care unit patients. Int Care Med 2013, 39(7):1253-1261

doi:10.1186/2197-425X-3-S1-A888

Cite this article as: Bonell Goytisolo et al:: Risk factors for mortality and multiresistant bacteria in bloodstream infections acquired in a private hospital intensive care unit. Intensive Care Medicine Experimental 2015 3(Suppl 1):A888.

\section{Submit your manuscript to a SpringerOpen ${ }^{\circ}$ journal and benefit from:}

- Convenient online submission

- Rigorous peer review

- Immediate publication on acceptance

- Open access: articles freely available online

- High visibility within the field

- Retaining the copyright to your article 